Research article

\title{
Rural change and farming resilience 'on the ground': approaching a relational perspective to strengthen local governance in the Brazilian countryside
}

\author{
Felipe da Silva Machado* \\ Federal University of Rio de Janeiro, Brazil
}

\begin{abstract}
Globalisation in a rural context has commonly focused on large-scale structural changes, transnational commodity chains or dramatic examples of rapid spatial transformations. The challenges for rural areas in the early twenty-first century such as local governance and resilience of communities to macro-scalar lock-in effects have also received more attention. This article argues that processes of rural change and farming resilience should be investigated 'on the ground' where it will lead to tangible changes in the social community interactions and local micro-politics. Different types of knowledge, organisations, innovationsand cross-scale linkages are part of this relational process in which rural actors (e.g. small-scale farmers and their farming communities) are proactive in the face of rural change. The article highlights theoretical patterns and processes of resilience and local governance, bringing in examples from the rural periphery of Greater Rio de Janeiro, where farming communities have adapted to new scenarios that have arisen over the past decades in the context of urbanisation and industrialisation in Brazil.
\end{abstract}

Keywords: Rural change; Farming resilience; Local governance; Small-scale farming strategies; Greater Rio de Janeiro (Brazil).

\section{Introduction}

The repercussions of challenges for rural areas in the developing world in the early twenty-first century, such as the political economy of new strategies for economic development based on the useand management of resources and the resilience of rural communities to globalisation, have received increasing academic attention in recent years (Wilson, 2012; Woods, 2012; Machado, 2017). As a result, one interesting and challenging research perspective to emerge from this theoretical discussion relates to the notion of social resilience in the era of globalisation and uncertainty. 
p. 233. Rural change and farming resilience 'on the ground': approaching a relational perspective to strengthen local governance in the Brazilian countryside

Indeed, since the early 1970 s notions of rural change have provided an important conceptual framework to understand how rural spaces respond and adapt to economic, societal and environmental changes (Marsden, 1996; Pierce, 1996; Ilbery, 1998). The complexity of spatial restructuring in the developed and developing worlds under globalisation requires a deeper understanding of the contem porary rural, going beyond viewing them as inert spaces subject to external interferences. Cutter et al. (2008) and Wilson $(2010,2012)$ indicated that there is a need for further research in rural arenas, arguing that processes of resilience should be measured and monitored at the local level.

At this scale different rural patterns are also driven and shaped by local social, economic and political forces that reflect distinctive social and geographical contexts (Marsden, 2003). The focus for rural studies has therefore been placed on the local community level, as it is here that the spatiality of resilience is implemented "on the ground' (Seymour, 2004; Parnwell, 2007; Wilson, 2010, 2012). The justification for this is both analytical and pragmatic. As commentators such as Agrawal and Gibson (1999), Chaskin (2008) and Wilson (2012) em phasised, over the past decades there has been a resurgence in attention to the community as a critical arena for analysing a range of issues, including societal pathways of change and the resilience of local actors. To address these issues, this article questions how small-scale farming communities have addressed resilience in the context of rural change.

Local development may be deemed to result from coherent initiatives and actions, based on the mobilisation of local social actors who agree to contribute expertise and assistance to improve specific territories. Actors ora group of actors may contribute to all four functions necessary and required for developing a territory: information, integration, planning and action (Clément and Bryant, 2004: 191). Participation, cooperation, joint work and the construction of partnerships give rise to networks of local actors who devise strategies of resistance, resilience or adaptation of rural communities to new global contexts (Wilson, 2012). A similar concern is present in assessments of environmental impacts and in socioeconomic policy in developing countries that highlight the need for integrating local knowledge into planning and evaluation of development projects (Bryant et al., 2004).

This article explains resilience theory and how it can be used as a concept for understanding the link between rural change, globalisation and farming community resilience in a global era, illustrated by the case of farming communities in the rural periphery of Greater Rio de Janeiro and highlighting the importance of building upon academic knowledge of farming resilience in a metropolitan fringe context. Specific focus is placed on how resilience theory can help foster better understanding of critical issues related to rural change and farming resilience in the face of globalisation processes. The importance of resilience theory in the social sciences is linked to recent radical changes in conceptualisations of societal change associated with the political ecology and cultural turn approaches. Davoudi (2012) argued that resilience provides a 'bridging concept', rather than an off-the-shelf rural development model. Within this context, resilience thinking offers two key contributions to rural studies, according to Scott (2013). Firstly, it offers alternative analytical methods and insights for rural studies; and, secondly, it provides an alternative policy narrative for rural development policy and practice.

The complexity of spatial restructuring over time in the rural periphery of Greater Rio de Janeiro is investigated to better understand rural change by going beyond the view of inert rural spaces subject to external linear global forces. For this reason, the author argues for a multidimensional and relational perspective to analyse the global ruralurban interface of the Brazilian countryside by examining the interaction of both urbanglobal expansion and the social resilient context of different parts of the area through 
p. 234. Rural change and farming resilience 'on the ground': approaching a relational perspective to strengthen local governance in the Brazilian countryside

analysing farming systems undergoing processes of change. Based on Berkes (2007) and Darnhofer (2010), the study identifiesfour main factors thatcreate resilient systems at farm level: 1) learning from changes and uncertainties; 2) nurturing spatial diversity in its various forms; 3) combining different types of knowledge and learning; and 4) creating opportunities for social organisation, relational and multi-scalar links.

\section{Resilience in a global era}

Globalisation is characterised by time-space compression and the acceleration of worldwide social relations which are transforming the structure and scale of human relationships as economic, social and environmental processes operate at a global rather than regional/local scales (Gray, 2002). Thus, globalisation refers to the increasingly global economic interlinkages between geographical spaces, the embeddedness of local communities within complex financial and monetary flows, and processes associated with increasingly uniform patterns of economic interconnectedness and embeddedness across the globe (Rofe, 2009).

Wilson (2012) investigated the notion of resilience and challenges faced by local communities around the world in dealing with disturbances that may threaten their longterm survival. Using global examples, he placed specific emphasis on how learning processes, traditions, policiesand politics affect the resilience of communities and what constraints and opportunities exist for communities to raise resilience levels. He also highlighted how certain types of community are losing resilience through increased embeddedness into globalised pathways of decision-making, while others may be gaining resilience, although no one system is either totally resilient or totally vulnerable.

Building on existing community resilience literature which highlights the importance of different socio-economic and political drivers for understanding community resilience, Kelly et al. (2015) analysed how economic, political, institutional, social, cultural and natural factors at community level affect the ability of communities to adapt and adjust decision-making pathways towards resilience. They argued that community resilience is the existence, development, and engagement of community resources by community members to thrive in an environment characterised by change, uncertainty, unpredictability, and surprise. Members of resilient communities intentionally develop personal and collective capacity that they engage to respond to and influence change, to sustain and renew the community, and to develop new trajectories for the community's future (Kelly et al., 2015:11).

Over the past two decades, there has been an increase in studies examining aspects of resilience at community level, with those focusing on social resilience particularly highlighting the importance of learning pathways, social memory and communication in enabling communities exposed to disturbances, hazards or catastrophes to adapt, change and adjust decision-making pathways (Cutter et al., 2008; Davidson, 2010).

Social factors are also crucial for resilience because they mediate the relationship between the socio-economic and environmental components of the system. Social factors include levels of interaction between community members such as trust, relationships, conflict resolution processes, engagement of young and old people, learning and communication pathways, cooperation, strength of networks, bonding and bridging capitals, as well as community cohesiveness (Cutter et al., 2008; Wilson, 2010, 2012).

The institutional domain includes closely inter-connected factors linked to politics, governance and institutional bodies and structures. Political factors are broadly linked to predominant ideologies and worldviews held by local, regional and national decision- 
p. 235. Rural change and farming resilience 'on the ground': approaching a relational perspective to strengthen local governance in the Brazilian countryside

makers. Political pathways are particularly affected by the type of political system (e.g. democratic, autocratic) and whether and how policy is enacted on the ground (Kelly et al., 2015: 13). Changes in policy can also have positive impacts, locking-in development to more sustainable pathways (Wilson, 2013). Moreover, learning pathways are often closely linked to the political domain, although the macro-scalar nature of most political processes means that change at the nation-state level or beyond is usually slower than at community level (Cumming et al., 2006).

In summarising the above narrative (see Table 1), resilience can help us understand and respond to the challenges of the contemporary age. As the concept of resilience has taken hold, these challenges are characterised by high uncertainty, globalised and interconnected systems, increasing disparities and limited choices. According to Brown (2016), resilience concepts can overturn orthodox approaches to international development that remain dominated by modernisation, aid dependency and a focus on economic growth, and to global environmental change, often characterised by technocratic approaches.

Table 1: Resilience theory ideas about development in an age of uncertainty and recurrent crises (source: author based on the references)

\begin{tabular}{|l|l|}
\hline \multicolumn{2}{|l|}{ Resilience theory } \\
\hline Brown (2016) & $\begin{array}{l}\text { Resilience concepts can overturn orthod ox approaches to } \\
\text { international development that remain dominated by modernisation } \\
\text { and a focus on economic growth, characterised by technocratic } \\
\text { approaches. }\end{array}$ \\
\hline Lendvay (2016) & $\begin{array}{l}\text { Resilience in human geography should dissolve the theoretical } \\
\text { dichotomy and treat both large scale structures and agency of } \\
\text { individuals on the common ontological framework. }\end{array}$ \\
\hline Scott (2013) & $\begin{array}{l}\text { Resilience thinking opens up new perspectives and provides the } \\
\text { potential to 're-frame' rural studies debates. } \\
\text { 1- resilience offers alternative analytical methods and insights for } \\
\text { rural studies; and 2-resilience provides an alternative policy narrative } \\
\text { for rural development. }\end{array}$ \\
\hline Welsh (2014) & $\begin{array}{l}\text { A critical interrogation of plural resilience theories, questioning their } \\
\text { emancipatory possibilities, calling for a more sustained and critical } \\
\text { engagement by human geographers with resilience studies and their } \\
\text { effects. }\end{array}$ \\
\hline Wilson (2012) & $\begin{array}{l}\text { Explored the links between resilience and transition theory, how path } \\
\text { dependencies affect resilience at community level, the impacts of } \\
\text { globalisation on different community trajectories, and the importance } \\
\text { of social memory for understandingconstraints and opportunities for } \\
\text { developing community resilience. }\end{array}$ \\
\hline
\end{tabular}


p. 236. Rural change and farming resilience 'on the ground': approaching a relational perspective to strengthen local governance in the Brazilian countryside

\section{Rural change and resilience in a global era}

Woods (2007) called for a new, multidimensional research agenda that emphasises the importance of place-based research for rural studies. At the same time, localised resistance to globalisation processes in both the Global North and the Global South has become a prominent feature of contestations over the meaningand use of rural space and, as such, a significant focus for research concerned with the relational entanglement of networks, processes and actors involved in its everyday reproduction.

Understanding these place-specific relations to the global requires, on the one hand, paying attention to the agency of local actors, whilst on the other also examining the broader economic and political relations - both historical and contemporary - which locate places within wider networks, along the lines outlined by Massey (2005). Applying this to rural contexts, Woods (2007) introduced the global countrysideas a hypothetical space representing the ultimate outcomes of globalisation processes. This space is yet to be fully attained but is shown to be partially articulated to greater/lesser degrees in different rural localities based on locally specific engagements with and responses to globalisation involving both humanand non-human actors.

Among these alternative pathways, an important but relatively less studied trajectory works through the effects of globalisation on local ecosystems. Local ecosystems constitute a critical link because the rural poor in developing countries derive a large part of their incomes from local, natural resource-based activitiessuch as crop and livestock production, fishing, hunting, fuelwood, and minor forest product collection (Aggarwal, 2006). Thus, it becomes natural to ask how globalisation, in its various dimensions, affects the local ecosystem, and thus the wellbeing of the rural poor who depend on it.

As ecologists point out, it is these cross-scale interactions that determine system behaviour. Drawing upon this insight, Aggarwal (2006) showed how globalisation can be viewed as an external shock that brings about rapid change in some variables (like prices or technologies) while other variables (like institutions and culture) remain sluggish. Wilson's (2012) work on the resilience of communities in both developedand developing world contexts particularly pointed towards the fact that community resilience and environmental transitions contribute towards academic debates that argue that 'social resilience' (the resilience of human systems) is crucial for understanding constraints and opportunities faced by communities in a rapidly changing world.

Wilson (2012) analysed specifically how environmental, political and socio-economic transitions affect community resilience and suggested that community embeddedness into the globalised world can both raise and reduce community-level resilience. Wilson's study emphasised that relocalised community pathways in particular highlight how communities are attempting to recapture lost social and environmental capital to increase community resilience. Until recently, communities facing such changes were almost entirely restricted to developed countries, where the gradual loss of agriculture's position and importance in society has been particularly pronounced since the $1950 \mathrm{~s}$. However, increasingly, rural communities in the South are also characterised by processes of rapid deagrarianisation (Bryceson and Jamal, 1997; Bryceson, 2002; Rigg 2006).

A key contribution of Wilson's work on resilience is his examination of the temporal evolution of rural systems and the unfolding trajectories of contrasting development paths: from relocalised low-intensity rural systems to deagrarianised rural communities and superproductivist rural systems. Similar to the literature within regional studies, Wilson identified exam ples of suboptimal 'locked-in' development paths in rural systems and argued that there are substantial limits to how the local level can shape and influence alternative path creation processes. This re-emphasises the need for 
p. 237. Rural change and farming resilience 'on the ground': approaching a relational perspective to strengthen local governance in the Brazilian countryside

mobilising a combination of local and extra-local resources in building more resilient futures.

The different approaches to rural resilience tend either to focus on structures, materials, and establishments or to foreground the agency of community members as individual actors. Recognising the shortcomings resulting from the gap between these two approaches (e.g., structuralism and post-structuralism), recently there have been calls for the dissolution of this binary division by applying a relational perspective focusing on interactions. Lendvay (2016) argued that resilience in human geography should dissolve the theoretical dichotomy and treat both large scale structures and agency of individuals in a common ontological framework, applying relational approaches.

As already mentioned, resilience thinking opens up new perspectives and provides the potential to reframe rural studies debates, providing a bridging concept that offers both alternative analytical methods and insights and provides a different policy narrative for rural development practice (Scott, 2013). This includes an emphasis on adaptive networked governance that embeds ecological concerns into rural development practices and a call for blending the local and global in rural development processes.

\section{Rural change and farming resilience 'on the ground'}

There is increasing consensus that change is accelerating and becoming less predictable, as global interconnections lead to events that produce consequences beyond their immediate context. Policy measures reinforce the impact of neoliberal agricultural policies and market deregulation. They also face the contradictory demands to increase food production to feed the rising world population while having to reduce the ecological impact of intensive production methods. Indeed, biodiversity is declining, soils are losing their organic matter, fresh water resources are being polluted (Darnhofer et al., 2016:111). These multifaceted dynamics and often contradictory demands may combine with sudden events such as volatile markets or food scares to generate unexpected outcomes.

Darnhofer et al. (2010) examined farming as part of a set of systems across spatial scales, from farm to global, and encompassing agro-ecological, economic and politicalsocial domains. Rather than a focus on production and efficiency, they argued that fam sustainability is achieved through adaptability, learning and change. Echoing the key themes within evolutionary economic geography, the authors suggested that in the case of the farming sector, resilience is more likely to emerge when farmers have the capacity to transform the farm, when farm production is attuned to the local ecological carrying capacity, and when learning and innovation are targeted outcomes.

Indeed, farms play an important role in maintaining social cohesion, producing food, providing energy from renewable resources, offering recreational and health care services, and maintaining the cultural landscape. At farm level, empirical studies have focused mostly on the structures that enable flexibility, which is seen as key to the ability of farms to adapt over time. It is little surprise, therefore, that within this context of economic turbulence and ecological instability, the concept of resilience at farm level has gained prominence both in political rhetoric and in research. Darnhofer et al. (2016) built specifically on the concept of social-ecological resilience (Holling, 2001), as it emphasises the interdependence of social and ecological dynamics - two key aspects of farming - and underlines the need to adapt and change, rather than the ability to buffer shocks and return to 'normal'. 
p. 238. Rural change and farming resilience 'on the ground': approaching a relational perspective to strengthen local governance in the Brazilian countryside

Bicalho and Machado's (2013) study of agricultural change in Brazil in the context of spatial transformations associated with the construction of a new petrochemical complex is an example of the processes that have taken place in the rural space of the metropolitan region of Rio de Janeiro. This study identified contradictions but also highlighted the persistence and resilience of rural space in which many farmers adapted to the new situation. The farmers have been able to resist conversion to urban uses by developing flexiblestrategies of capitalisation adapted to the availability of financial and human resources and by taking on selected quality products. However, not all farmers have seized these new opportunities. This study identified contradictions in land use policy which threaten farming, but also highlighted the resilience of rural space whereby some farmers have adapted to new situations that arose. New rural-urban interactions contribute to complex outcomes in which local actors create new forms of spatial ordering and so adapt to new scenarios of change.

Fonte (2008) highlighted that during the industrialisation of agriculture, the role of farmers' knowledge has greatly diminished and much of this knowledge has become lost altogether due to the spread of productivist logic, standardised solutions and a decline in the size of farming communities and their sense of cohesion. However, in the face of the many contemporary challenges facing agriculture: climate change, food security and resource depletion, to name but a few, there is an emerging recognition that farmers and local knowledge is a valuable resource that can reorient modern agriculture towards more sustainable and resilient paths of development (Šūmane et al., 2018: 232).

In recent years, agricultural sustainability has been linked with the concept of resilience, which emphasises dynamics, disequilibrium and unpredictability in agricultural development. Learning to live with change and uncertainty and combining different types of knowledge appear to be critical for building resilience because change appears to be needed to develop adaptive capacity (Folke et al., 2003). Among the diverse knowledge sources and learning forms that farmers use, Darnhofer et al. (2016) have pointed to the particular role of farmers' experimental learning and networking in increasing the resilience of small-scale farmers. Thus, Šumane et al., (2018) related the potential of informal knowledge in improving sustainability and resilience to its embeddedness in the specific social, economic and environmental contexts and its holistic character and dynamics in response to emerging opportunities, uncertainties and risks.

Farmers' informal knowledge is often compared and contrasted to formal knowledge. According to Šūmane et al. (2018), it is helpful to compare informal and formal knowledge as this illuminates the different characteristics and usefulness of each type. However, it does not accurately reflect the reality of farming in which farmers often integrate and use all the kinds of knowledge that they haveaccess to or which they find relevant. The seeming differences between scientific and informal knowledge regarding their content, methods, epistemology and contextual embeddedness are too simplistic (Šūmane et al., 2018:234).

Local knowledge can be scientifically valid, and scientific knowledge can provide solutions for very specific local contexts. Somestudies have indicated that farmers tend to value and rely more on practice-based knowledge (Lyon et al., 2011), and are able to mobilise this knowledge to resist scientific discourse (Clark and Murdoch, 1997). Local knowledge has relevance for agricultural sustainability and resilience, as it tends to be holistic, dynamic and adaptive in character.

Combining different types of knowledge is related to the ability to incorporate scientific information into traditional knowledge bases, and the ability to share insights, to bring together parties with different strengths in terms of knowledge and backgrounds, and thus to create learning environments (Berkes, 2007). At the farm level this can be 
p. 239. Rural change and farming resilience 'on the ground': approaching a relational perspective to strengthen local governance in the Brazilian countryside

found in the variety of information sources that farmers tap into and use to make decisions, in the variety of networks in which they are involved, and in their ability to build on experiences and traditions.

In conclusion, the different approachesto rural resilience seem either to privilege the material structures or to highlight that the agency of farmers and other social groups plays an important role. Thus, while the importance of interactions between the ecological and social domain is acknowledged, it remains a challenge to fully integrate both domains, while at the same time capturing the dynamics of on-going change.

\section{Strategies to strengthen farming resilience in the rural periphery of Greater Rio de Janeiro (Brazil): abilities of farmers to maintain the local capacity for social organisation}

A relational perspective on the resilience of farms can contribute to overcoming the conceptual distinction between the actor and his/her activity, structureand agency, and the social and ecological. It focuses on relations rather than entities and allows for a symmetric treatment and enhanced integration. Indeed, relational theorists reject the notion that there are discrete, pre-given units that can be used as a starting point of analysis (Emirbayer, 1997). According to Darnhofer et al. (2016), from a relational perspective farmers are understood as inseparable from the spatial and temporal contexts within which they are embedded. This section discussesthe social organisation capacity of farmers in the context of rural-urban interactions in the metropolitan countryside of Rio de Janeiro, in which organisational strategy becomes a critical issue for strengthening resilience processes. One of the trajectories observed has been the articulation of farmer communities with external actors and public institutions through processes of interaction and cooperation at multiple scales.

The section discusses the ability of farmers and their strategies to maintain local capacity for social organisation and governance within these interactions. In the processes of dialogue with external actors and formal institutions, interactions and knowledge exchanges have been established beyond the local scale, allowing community members and farmers' associations to interact with external actors and organisations on different scalar levels. Such interactions can create links that involve other formal institutions and social organisations from diffe rent rural locations that are part of the same regional context This environment of learning, knowledge exchange and cooperation enables processes of innovation that go beyond individualised knowledge and practice. This wider network of social organisation has given rise to a diversity of ideas and voices that reveal the challenges of agriculture in the context of multifunctionality and multifaceted interaction.

The relationship between formal institutions and farmers can result in interactions for building governance processes. These interactions can also create spaces of challenge and political engagement for voices that oppose productivist agriculture by promoting alternative discourses within the social organisation that becomes more diverse and multidirectional. Finally, conclusions are drawn from the case study concerning the debate on social organisation by the farming community as part of their strategies to strengthen farming resilience in the rural periphery of Greater Rio de Janeiro.

Associations of small farmers in Brazil have grown in number since the 1980s, stimulated by national policies that recognise, on the one hand, that agricultural policies are more effective when managed collectively and, on the other, that formalise participatory action by local actors (Caldeira, 2008; Bicalho, 2009; Schneider et al., 
p. 240. Rural change and farming resilience 'on the ground': approaching a relational perspective to strengthen local governance in the Brazilian countryside

2010). The peripheral countryside of Rio de Janeiro Metropolitan Region is characterised by small, predominantly family farms, and there is a history of social organisation dating back to the 1960s. This section assesses the role of farmers' associations in establishing strategies to support small-scale farmers in the area and evaluates their relations with external institutions and cross-scale policies.

Agricultural policy in Brazil has mainly involved processes of agricultural modernisation that stimulated and strengthened large capital-intensive farms. In sporadic and localised cases, small-scale farmers were included in agricultural development programmes, such as irrigation projects in Northeast Brazil (Bicalho and Hoefle, 1990). The management of these government projects often imposed a cooperative model by forming an economic institution under the tutelage of rural extension officers from federal agencies, who directly administered production by the families involved. The cooperative model has not always produced its desired outcomes or commitment by participating farmers unless they were kept under the authoritarian control of the centralised administration.

This process of authoritarian control and the formation of small-scale farmers' cooperatives followed the modernisation ethos in Brazilian agriculture, underpinned by an ideology that economic efficiency and return on the capital investments would be obtained through economies of scale. In the case of small-scale farmers, this was pursued by grouping farmers into collective organisations, preferably a cooperative with equity guarantees and legal status that enabled it to operate in the commercial arena. This model was mostlyalien to its members and did not flourish as intended (Delgado, 1985; Rocha, 1999).

Collective organisation is nevertheless still seen by many in governing bodies as the most efficient way for diffusing modern techniques. Farmers' traditional experience and knowledge were not valued and utilised, but were seen as in need of replacement by new processes and production systems based around high investment in capital inputs. In addition to the high costs to the farmers and the disregard for their agricultural practices, the closed technological package of modern agriculture made it impossible to include smallholders in agricultural proposals and policies (Chambers, 1983; Shiva, 1991; van der Ploeg, 2009).

However, faced with direct state intervention policies, many small-scale farmers established their own strategies that adjusted these new techniques and inputs to their resources and interests, combining old and new technologies from their experience and knowledge (Bicalho, 1999; Ricardio, 2011). The strengthening of the group came about through endogenous social organisation in production and marketing cooperatives, or associations of residents and farmers with mixed social and economic objectives based on local needs. In this way, an endogenous movement was established, based on the demands and characteristics of the social group.

Greater approximation of agricultural policy with the realities of small-scale farming can be identified at the outset of the 1980s with the adoption of new approaches to promoting modernisation via an integrated development model that articulated local techniques, communities and natural resources (Chambers, 1983; Richards, 1985; Chambers et al., 1989). The transfer of modern technologies to farmers was maintained, but with better management of natural resources likesoil and water. For example, a local farmer reported about the Rio de Janeiro Sustainable Rural Development Project - Rio Rural funded by the World Bank and the United Nations Food and Agriculture Organisation (FAO) which has offered subsidies to the rural community in the municipality of Cachoeiras de Macacu, Rio de Janeiro state. 
p. 241. Rural change and farming resilience 'on the ground': approaching a relational perspective to strengthen local governance in the Brazilian countryside

Agricultural policy nevertheless remained centred on achieving modern agricultural standards in Brazil. The implementation of integrated planning in micro-basins was strongly technocratic, assuming that communities were defined by the basin and the research and extension services provided would correspond to the farmers' needs. Social dynamics were mostly ignored in the underlying discourse, and an environmental determinist outlook led to a focus on the dynamics of river basins, rather than the specific features of different farming locations. For example, the rural community of Faraó in Cachoeiras de Macacu is situated between basins on the escarpment of the Serra do Mar coastal mountains in a buffer zone of the Three Peaks State Park, an important conservation unit of the Atlantic Forest biome.

Therefore, a recurring problem has been 'top-down' action and the imposition of decisions and plans that were often inadequate for the social and economic dynamics of areas or regions. Priorities stand out to change this picture. One of these is the reorientation of agricultural policy affecting small-scale farmers, focusing on the social, economic and locational distinctiveness of family agriculture and the development of alternatives to the simple transfer of modern technology. Keeping the perspective that social organisations have broader effects, this policy in Rio de Janeiro and other Brazilian states has em phasised programmes directed at associations and cooperatives of sm allscale farmers. The main difference from previous arrangements is that policy could be directed to social organisations which met certain criteria. International organisations with a new focus on environmental issues such as The World Bank have also participated, reinforcing the integration of environmental policies with local communities and the use of participatory governance processes.

Other programmes like the National School Meal Programme (PNAE) are not directly aimed at promoting the agricultural sector, but have had repercussions on production and on small-scale farmers in the case study area, once dependent solely on food production. These include different food and nutrition policy programmes for low-income populations and policies for supplying large urban centres. Policies on school meals for low-income households were first formulated in the 1930s, recognising the problem of malnutrition as a national issue (Prado Júnior, 1942; de Castro, 1946), but programmes of this nature are still operating (BRASIL, 2009; Sonnino et al., 2014; Kleine and Brightwell, 2015). In contrast to the past, the management of programmes are now decentralised, having been assumed by the state and municipal governments. In the case of school meals, the policy recently innovated with the formalisation of its relationship with family farming. The association of nutrition policy with family farming policy has markedly benefitted food production on small-scale farms. Since this privileges socially organised farmers, it stimulates the formation and strengthening of small-scale farmers' associations.

Between August and December 2017 I participated in a series of meetings with farmers, a rural extension company and the Department of Agriculture of Tanguá at the ACIPTA (Association of Citrus Growers and Rural Producers of Tanguá) in the rural periphery of Rio de Janeiro. The meetings discussed different themes to promote improvements in agriculture in the rural locality and surrounding areas, integrating family farmers with localand regional public institutions responsible for rural development. This was more than a forum for technical discussions and knowledge sharing; in the process the association's head office became a centre of social organisation in the community (see Figures 1 and 2). 
p. 242. Rural change and farming resilience 'on the ground': approaching a relational perspective to strengthen local governance in the Brazilian countryside

Figure 1: Farmers share information and knowledges at the farmers' association head office, Tanguá, Rio de Janeiro

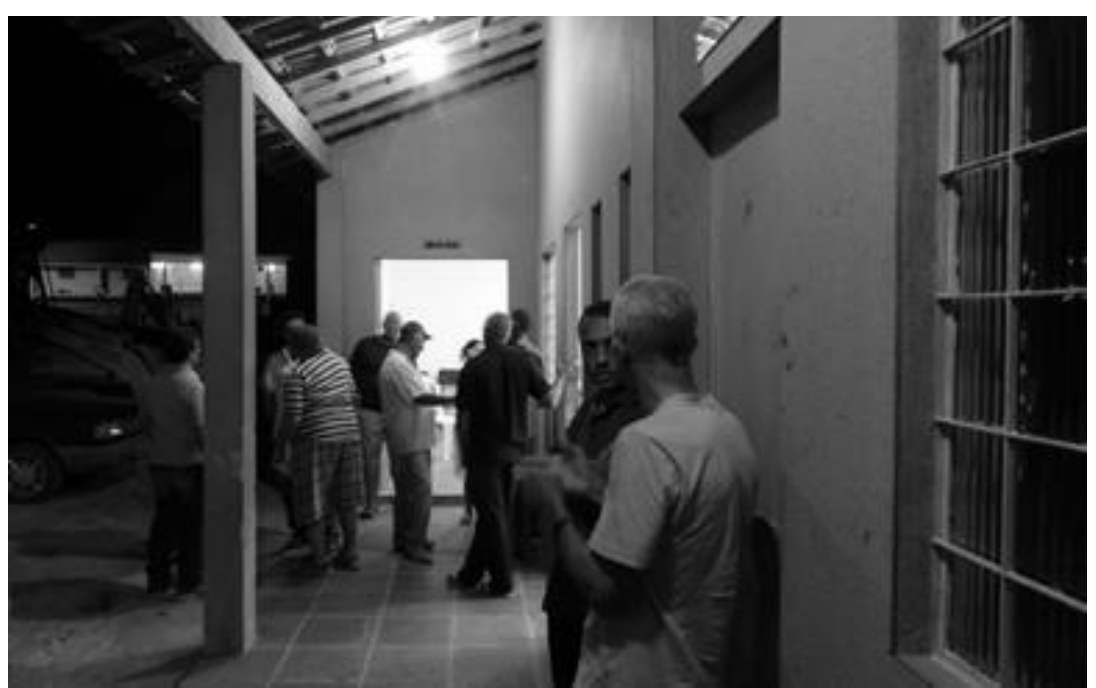

Source: Author, 2017

Figure 2: A rural extension official prepares the session room at the farmers' association head office, which holds meetings between farmers and institutions every Wednesday in the rural locality of Posse dos Coutinhos, Tanguá, Rio de Janeiro

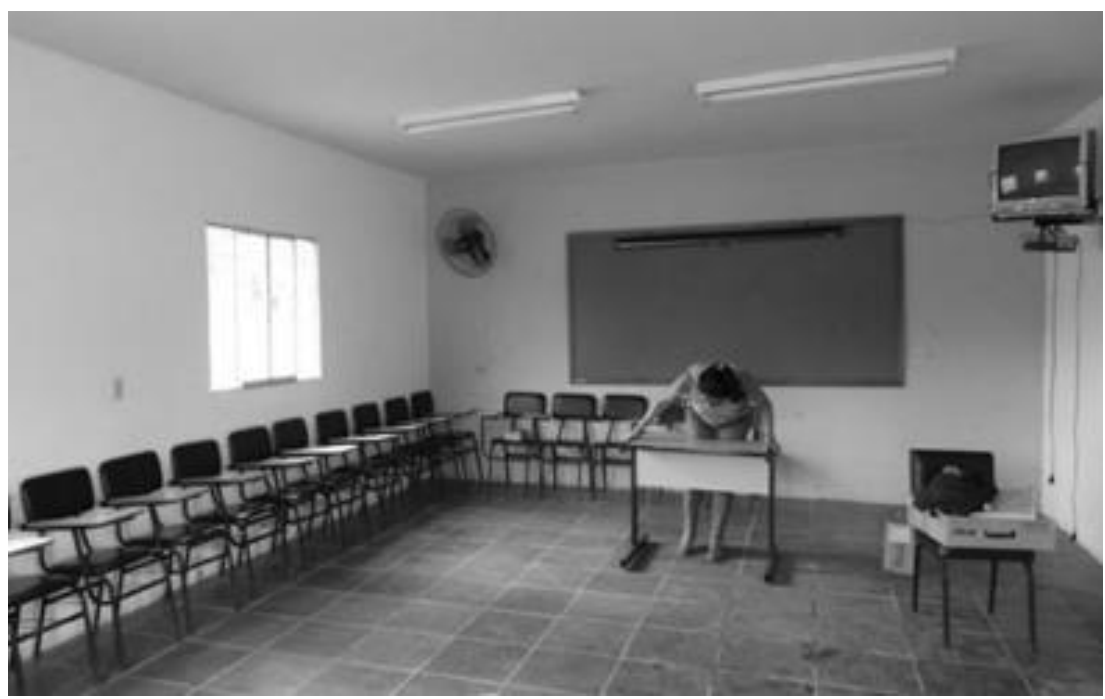

Source: Author, 2017

The revival of the farmers' association in the municipality of Tanguá, Rio de Janeiro Metropolis reveals processes of resilience among this group of farmers. The area has undergone spatial changes resulting from its position in the context of urban expansion and industrialisation in the wider Rio de Janeiro Metropolitan Area. Although it remains rural in character and most land is still used for agricultural purposes, there are trends towards the expansion of housing plots and the conversion of land to pasture, which favours eventual subdivision and development as housing plots. The permanence of fruit farming is an indicator of resistance and adaptation in the context of conflict of land use. Therefore, the farmers' association in the rural locality of Posse dos Coutinhos, Tanguá 
p. 243. Rural change and farming resilience 'on the ground': approaching a relational perspective to strengthen local governance in the Brazilian countryside

has sought to strengthen fruit farming through social organisation (see Figures 3 and 4). Increasing competition from industrial, residential and environmental functions present both opportunity and conflict for rural activities and so create a mosaic of diversified land use in the metropolitan space. Some changes do not necessarily cause agricultural decline, but instead can induce rural development and adaptation where rural diversity responds to new demands of contemporary Brazilian society in the context of globalization.

Figure 3: ACIPTA (Association of Citrus Growers and Rural Producers of Tanguá), Posse dos Coutinhos, Tanguá, Rio de Janeiro

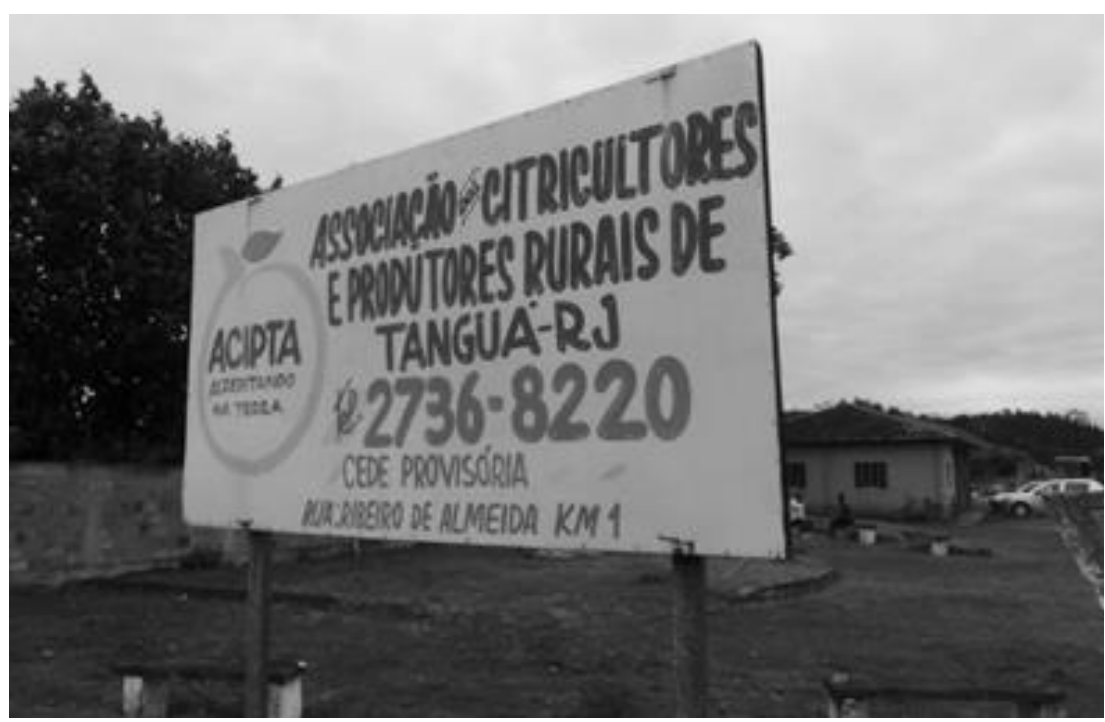

Source: Author, 2017

Figure 4: Morethan a place for agricultural technical discussionsand knowledge sharing the association's office has become one of the core places for social organisation and mobilisation in the rural community of Posse dos Coutinhos, Tanguá, Rio de Janeiro

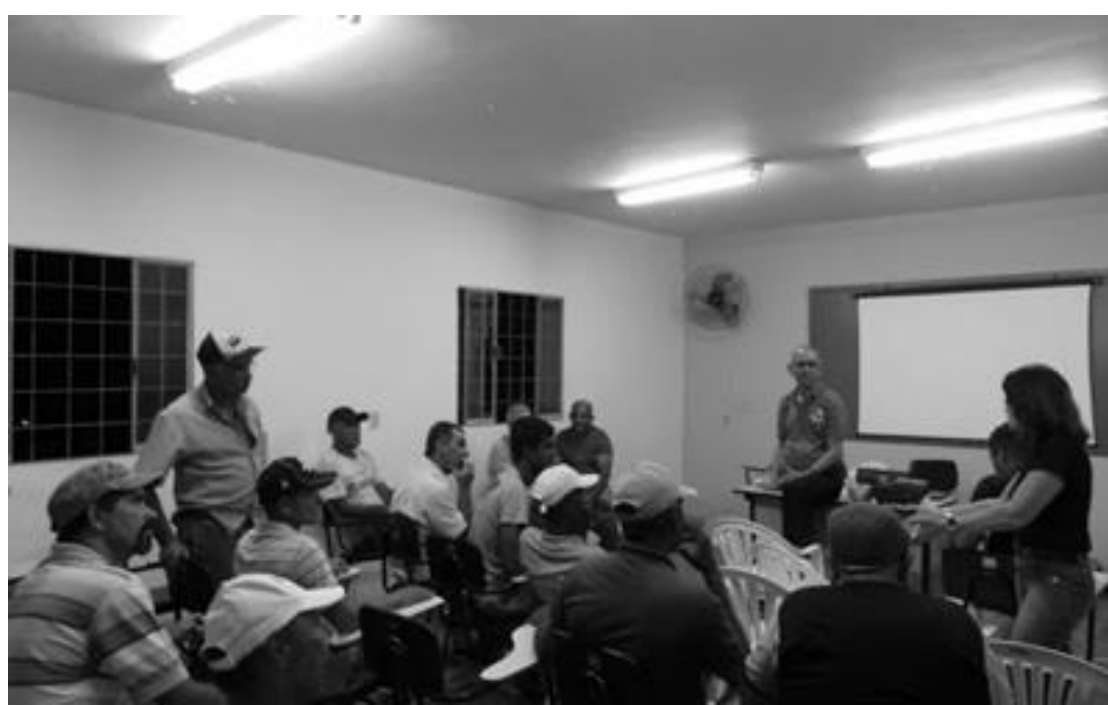

Source: Author, 2017 
p. 244. Rural change and farming resilience 'on the ground': approaching a relational perspective to strengthen local governance in the Brazilian countryside

One group of small-scale farmers has developed strategies to strengthen social organisation and to improve the fruit productivity through the organisation of 'multirão' 1 to promote mutual aid among participants. This group meets weekly as a mechanism for overcoming labour shortages and more generally to promote cooperation among members of the farming community. Another example of cooperation was observed between two farmers who leased a small area near the source of the river, allowing irrigation for passion fruit cultivation on a small piece of land. Although the production area is small, passion fruit guarantees higher income and better value in agricultural markets in summertime. The 'multirão' has now helped to extend his original initiative to other farmers and suitable plots, providing a good exam ple of the benefits of close links between farmers and multifunctional agriculture going beyond productivism logic. Lamine (2012) found that farmers belonged to several, partially intersecting, informal networks in which they shared equipment, sometimes worked together, and in most cases collaborated over logistics involved in commercialisation.

Although the relational approach raises innovative methodological challenges, nevertheless its application has shown how the 'vibrancy' of matterand the interaction can be effectively captured (Darnhofer et al., 2016: 120). The case study outlined in this section shows that social and organisational innovation can play a vital role in renewal at farm level and in rural economies at the rural-urban interface. In the specific instance of the Rio de Janeiro Metropolitan Region rural fringe, farmers have combined social strategies creatively to adapt to spatial change and to strengthen resilience.

\section{Conclusions}

In recent years sustainability has been associated with the concept of resilience, which emphasises dynamics, imbalance and unpredictability. Resilience refers to a system's ability to adapt and transform itself so that it can persist in the long term (Darnhofer, 2014). Learning to live with change and uncertainty and combining different types of knowledge appear critical for building resilience (Folke et al., 2003). Welsh (2014) argued a critical interrogation of plural resilience theories and wonders at their emancipatory possibilities.

Many historical instances of rural change were revolutionary for those directly affected but were spatially limited. In contrast, today's processes of rural change resound around the globe. Rural areas, it seems, are interconnected by global social and economic processes that cut across rural and urban space in a condition of advanced globalisation. The rural is, and always has been, a dynamic and diverse space, made elusive by its relationality. The idea of the rural has had a powerful resonance throughout history and has attracted, inspired and confounded geographers in equal measure (Woods, 2011: 293).

According to Woods (2005), contemporary rural change is distinguished by two characteristics. The first is the pace and persistence of change. Rural economies and societies are not just changing, but changing constantly and rapidly, affected by successive trends and innovations that roll in like the waves of an incoming tide (Marsden et al., 1993; Hoggart and Paniagua, 2001; Woods, 2005, 2011). This vigorous pace of change is driven by the rate of technological innovation and social reform in late modernity. The second characteristic is the totality and interconnectivity of change.

As highlighted in this article, the concept of resilience can serve as the theoretical basis for understanding global interaction in the context of recent social and economic change resulting from global drivers in rural spaces and farming communities. Building on work by Marsden et al. (1993), Wilson $(2007,2010)$ and Woods $(2007,2011)$ this 
p. 245. Rural change and farming resilience 'on the ground': approaching a relational perspective to strengthen local governance in the Brazilian countryside

article has endeavoured to build the case for analysing rural change in relation to the interaction of both endogenous and exogenous forces 'on the ground', at the same time as recognising the importance of globalisation and spatial restructuring in the creation of a space with different premises.

Following conservative turn in 2017, neoliberal and right-wing political groups have governed Brazil and agricultural policies in the current era have usually focused on making agribusiness-farming systems more robust against shocks in the short term. Nevertheless, small-scale farming accounts for up to 65 per cent of some of the countrys staple food production, employs the majority of the farm labour force and is responsible for one third of agricultural income (based on the Census of Agriculture: IBGE, 2017). For those reasons, a broader view of rural change and resilience is needed to ensure a sustainable small-scale agricultural sector in Brazil, which can develop farmer capacities, adapt farming systems to changing circumstances and transform their agricultural models in order to maintain long-term supply of food and public goods.

\section{Notes}

1 According to the 'Historical Dictionary of Brazil' by Levine (1979), 'multirão' is community efforts to help an individual or family, usually in the construction of a house, corral, or in the field in the case of hardship.

\section{Acknowledgements}

The doctoral research on which this article is based was funded by the Coordenação de Aperfeiçoamento de Pessoal de Nível Superior (CAPES-Brazil), the Conselho Nacional de Desenvolvimento Científico e Tecnológico (CNPq-Brazil)and the Fundação Carlos Chagas Filho de Amparo à Pesquisa do Estado do Rio de Janeiro (FAPERJ-Brazil). The author would also like to thank Professor Geoff Wilson for his invaluable help and guidance during this period of PhD research at the University of Plymouth, United Kingdom.

*Correspondence address: Felipe da Silva Machado, Post-doctoral Researcher, Department of Geography, Federal University of Rio de Janeiro, Av. Pedro Calmon, 500 Cidade Universitária, Rio de Janeiro - RJ, 21941-901, Brazil. Email: felipemachado1@gmail.com

\section{References}

Aggarwal, R.M. (2006) Globalisation, local ecosystems, and the rural poor. World Development, 34, 8, 1405-1418.

Agrawal, A. and Gibson, C.C. (1999) Enchantment and disenchantment: the role of community in natural resource conservation. World Development, 27, 629-649.

Berkes, F. (2007) Understanding uncertainty and reducing vulnerability: lessons from resilience thinking. Natural Hazards, 41, 283-295.

Bicalho, A.M.S.M. (1999) Comunidade, planejamento rural e geografia. Revista da PósGraduação em Geografia UFRJ, 3, 164-186.

Bicalho, A.M.S.M. (2009) Capital social na várzea amazônica. In: Bicalho, A.M.S.M and Gomes, P.C.C. (eds.). Questões Metodológicas e Novas Temáticas na Pesquisa Geográfica. Rio de Janeiro: Publit, 93-122. 
p. 246. Rural change and farming resilience 'on the ground': approaching a relational perspective to strengthen local governance in the Brazilian countryside

Bicalho, A.M.S.M and Hoefle, S.W. (1990) Divergent Trends in Brazilian Rural Transformation: Capitalised Agriculture in the Agreste and Sertão of the Northeast. Bulletin of Latin American Research, 9, 1, 49-77.

Bicalho, A.M.S.M. and Machado, F.S. (2013) Do agrário ao periurbano: o município de Cachoeiras de Macacu na Região Metropolitana do Rio de Janeiro. Geografia (Rio Claro), 38, 545-564.

Brasil (2009) Ministério da Educação do Brasil. Programa Nacional de Alimentação Escolar (PNAE) Resolução/CD/FNDE N³8, de 16 de julho de 2009. Brasil, Brasília.

Brown, K. (2016) Resilience, Development and Global Change. London: Routledge.

Bryant, C.R., Doyon, M., Frej, S., Granjon, D. and Clément, C. (2004) The integration of environment into sustainable development practice and discourse through citizen participation and the mobilisation of local knowledge. In: Bicalho, A.M.S.M and Hoefle, S.W. (eds.). The Regional Dimension and Contemporary Challenges to Rural Sustainability. Rio de Janeiro: Laget-UFRJ/CSRS-UGI, 14-25.

Bryceson, D.F. (2002) Multiplex livelihoods in Rural Africa: recasting the terms and conditions of gainful employment. Journal of Modern African Studies, 40, 1, 1-28.

Bryceson, D.F. and Jamal, V. (eds.) (1997) Farewell to Farms: de-agrarianisation and employment in Africa. Aldershot: Ashgate.

Caldeira, R. (2008) My land, your social transformation: conflict within the Landless People Movement (MST), Rio de Janeiro, Brazil. Journal of Rural Studies, 24, 150160.

Chambers, R. (1983) Rural Development: Putting the Last First. Harlow: Prentice-Hall.

Chambers, R., Pacey, A. and Thrupp, L.A. (eds.) (1989) Farmer First: Farmer Innovation and Agricultural Research. London: Intermediate Technology Publications.

Chaskin, R.J. (2008) Resilience, community, and resilient communities: conditioning contexts and collective action. Child Care in Practice, 14, 1, 65-74.

Clark, J. and Murdoch, J. (1997) Local knowledge and the precarious extension of scientific networks: a reflection on three casestudies. Sociologia Ruralis, 37, 1, 3860.

Clément, C. and Bryant, C.R. (2004) Urban fringe horticulture in the Otawa. In: Bicalho, A.M.S.M and Hoefle, S.W. (eds.). The Regional Dimension and Contemporary Challenges to Rural Sustainability. Rio de Janeiro: Laget-UFRJ/CSRS-UGI, 187-202.

Cumming, G.S., Cumming, D.H. and Redman, C.L. (2006) Scale mismatches in socialecological systems: causes, consequences, and solutions. Ecology and Society, 11, $1,14$.

Cutter, S.L., Barnes, L., Berry, M., Burton, C., Evans, E., Tate, E. and Webb, J. (2008) A place-based model for understanding community resilience to natural disasters. Global Environmental Change, 18, 598-606.

Darnhofer, I. (2010) Strategies of family farms to strengthen their resilience. Environmental Policyand Governance, 20, 212-222.

Darnhofer, I. (2014) Resilience and why it matters for farm management. European Review of Agricultural Economics, 41, 461- 484.

Darnhofer, I., Lamine, C., Strauss, A. and Navarrete, M. (2016) The resilience of family farms: towards a relational approach. Journal of Rural Studies, 44, 111- 122.

Davidson, D.J. (2010) The applicability of the concept of resilience to social systems: some sources of optimism and nagging doubts. Societyand Natural Resources, 23 1135-1149.

Davoudi, S. (2012) Resilience: a bringing concept or a dead end?. Planning Theory and Practice, 13, 299-307.

de Castro, J. (1946) Geografia da Fome. Rio de Janeiro: Editora O Cruzeiro.

Delgado, G.C. (1985) Capital financeiro e agricultura no Brasil. São Paulo: Ícone/UNICAMP. 
p. 247. Rural change and farming resilience 'on the ground': approaching a relational perspective to strengthen local governance in the Brazilian countryside

Emirbayer, M. (1997) Manifesto for a relational sociology. American Journal of Sociology, $103,2,281-317$.

Folke, C., Colding, J. and Berkes, F. (2003) Building resilience and adaptive capacity in social-ecological systems. In: Berkes, F., Colding, J., Folke, C. (eds.) Navigating Social-Ecological Systems. Cambridge: Cambridge University Press, 352-473.

Fonte, M. (2008) Knowledge, Food and Place. A way of producing, a way of knowing. Sociologia Ruralis, 48, 3, 200-222.

Gray, J. (2002) False Dawn: The Delusions of Global Capitalism. London: Granta Books.

Hoggart, K. and Paniagua, A. (2001) What rural restructuring? Journal of Rural Studies, 17, 41-62.

Holling, C.S. (2001) Understanding the complexity of economic, ecological and social systems. Ecosystems, 4, 390-405.

IBGE (Instituto Brasileiro de Geografia e Estatística) (2017) Censo Agropecuário: Resultados Preliminares. Rio de Janeiro. Available at: www.ibge.gov.br

Ilbery, B. (ed.) (1998) The Geography of Rural Change. Essex: Longman.

Kelly, C., Ferrara, A., Wilson, G.A., Ripullone, F., Nole, A., Harmer, N. and Salvati, L. (2015) Community resilience and land degradation in forest and shrub land socioecological systems: a case study in Gorgoglione, Basilicata region, Italy. Land Use Policy, 46, 11-20.

Kleine, D. and Brightwell, M.D.G. (2015) Repoliticising and scaling-up ethical consumption: Lessons from public procurement for school meals in Brazil. Geoforum, 67, 135-147.

Lamine, C. (2012) Changer de système: une analyse des transitions vers l'agriculture biologique à l'échelle des systèmes agri-alimentaires territoriaux. Terrains and Travaux, 20, 139-156.

Lendvay, M. (2016) Resilience in post-socialist context: the case of a watermelon producing community in Hungary. Hungarian Geographical Bulletin, 65, 3, 255269.

Levine, R.M. (1979) Historical Dictionary of Brazil. Metuchen: Scarecrow Press.

Lyon, A., Bell, M.M., Gratton, C. and Jackson, R. (2011) Farming without a recipe: Wisconsin graziers and new directions for agricultural science. Journal of Rural Studies, 27, 384-393.

Machado, F.S. (2017) Rural change in the context of globalisation: examining theoretical issues. Hungarian Geographical Bulletin, 66, 43-53.

Marsden, T. (1996) Rural geography trend report: the social and political bases of rural restructuring. Progress in Human Geography, 20, 246-258.

Marsden, T. (2003) The Condition of Rural Sustainability. Assen: Royal Van Gorcum.

Marsden, T., Murdoch, J., Lowe, P., Munton, R. and Flynn, A. (1993) Constructing the Countryside. London: UCL Press Limited.

Massey, D. (2005) For Space. London: Sage.

Parnwell, M.J. (2007) Neolocalism and renascent social capital in northeast Thailand. Environment and Planning D: Society and Space, 25, 990-1014.

Pierce, J.T. (1996) The conservation challenge in sustaining rural environments. Joumal of Rural Studies, 12, 215-229.

Prado Júnior, C. (1942) Formação do Brasil Contemporâneo. São Paulo: Livraria Martins Editora.

Ricardio, L. (2011) A modernização conservadora da agricultura brasileira, agricultura familiar, agroecologia e pluriatividade: diferentes óticas de entendimento e de construção do espaço rural brasileiro. Cuadernos de Desarrollo Rural, 8, 67, 231249.

Richards, P. (1985) Indigenous Agricultural Revolution. London: Hutchinston.

Rigg, J. (2006) Land, farming, livelihoods, and poverty: rethinking the links in the rural South. World Development, 34, 1, 180-202. 
p. 248. Rural change and farming resilience 'on the ground': approaching a relational perspective to strengthen local governance in the Brazilian countryside

Rocha, E.E.R.B. (1999) O cooperativismo agrícola em transição. Doctoral thesis. Campinas: Instituto de Economia/UNICAMP.

Rofe, M.W. (2009) Globalisation, gentrification and spatial hierarchies in and beyond New South Wales: the local/global nexus. Geographical Research, 47, 3, 292-305.

Schneider, S., Shiki, S. and Belik, W. (2010) Rural development in Brazil: overcoming inequalities and building new markets. Rivista di Economia Agraria, 2, 225-259.

Scott, M. (2013) Resilience: a conceptual lens for rural studies? Geography Compass, 7 , $9,597-610$.

Seymour, S. (2004) Community-based strategies for environmental protection in rural areas: towards a new form of participatory rural governance? In: Holloway, L. and Kneafsey, M. (eds.) Geographies of Rural Cultures and Societies. Aldershot: Ashgate, 214-237.

Shiva, V. (1991) The Violence of the Green Revolution: Third World agriculture, ecology and politics. London: Zed Books.

Sonnino, R., Torres, C.L. and Schneider, S. (2014) Reflexive governance for food security. the example of school feeding in Brazil. Journal of Rural Studies, 36, 1-12.

Šūmane, S., Kunda, I., Knickel, K., Strauss, A., Tisenkopfs, T., de los Rios, I., Rivera, M., Chebach, T. and Ashkenazy, A. (2018) Local and farmers' knowledge matters! How integrating informal and formal knowledge enhances sustainable and resilient agriculture. Journal of Rural Studies, 59, 232-241.

van der Ploeg, J.D. (2009) The New Peasantries: New Struggles for Autonomy and Sustainability in an Era of Empire and Globalisation. London: Earthscan.

Welsh, M. (2014) Resilience and responsibility: governing uncertainty in a complex world. The Geographical Journal, 180, 15-26.

Wilson, G.A. (2007) Multifunctional Agriculture: A Transition Theory Perspective. Wallingford: $\mathrm{CABI}$.

Wilson, G.A. (2010) Multifunctional 'quality' and rural community resilience. Transactions of the Institute of British Geographers, 35, 3, 364-381.

Wilson, G.A. (2012) Community Resilience and Environmental Transitions. London: Earthscan.

Wilson, G.A. (2013) Community resilience, policy corridorsand the policy challenge. Land Use Policy, 31, 298-310.

Woods, M. (2005) Rural Geography: Processes, Responses and Experiences in Rural Restructuring. London: Sage.

Woods, M. (2007) Engaging the global countryside: globalisation, hybridity and the reconstitution of rural place. Progress in Human Geography, 31, 485-507.

Woods, M. (2011) Rural. Abingdon: Routledge.

Woods, M. (2012) New directions in rural studies? Journal of Rural Studies, 28, 1-4. 